\title{
The Dictates of the Market \\ The Future of Profession of Translators and Interpreters in a Post-Socialist EU-Member State
}

\author{
Nike K. Pokorn* \\ University of Ljubljana \\ 2 Askerceva, 1000, Ljubljana, Slovenia
}

Received 19.10.2015, received in revised form 04.12.2015, accepted 28.02.2016

The article outlines the changes of the profession of translators and interpreters, and the development of the translator and interpreter training at the university level in the Republic of Slovenia, one of the post-socialist EU member states, in the last 35 years. It also provides an insight into the present and future status of the profession by surveying the average earnings of junior translators in the Slovene and Russian translation and interpreting markets. Through an analysis of the public database containing information on all business entities in Slovenia, a description of the translation market in 2014 is made and the findings are compared to those of a similar study carried out in 2007, focusing on the changes that occurred as the result of the outsourcing and globalization of the profession. Finally, a survey of the graduates of the Department of Translation Studies, University of Ljubljana, and of four CIUTI translator - and interpreter-training higher-education institutions from Russia are presented, focusing in particular on graduate employment statistics and average earnings of junior translators and interpreters. On the basis of the description of the present status of the profession, it is concluded that the future of the profession of translators and interpreters is going to be influenced by the globalization of the translation business, the diminishing number of in-house translators and interpreters, and increased use of technology which will force the translators and interpreters to be flexible, ready to acquire new skills and accommodate quickly to market needs.

Keywords: translation market, professional translators and interpreters, globalization of translation business, education of translators and interpreters, average earnings of translators and interpreters in Slovenia and Russia.

DOI: 10.17516/1997-1370-2016-9-3-662-674.

Research area: philology.

\section{Introduction}

The aim of the article is to describe the changes the professions of translators and interpreters have undergone from Socialist times to the present day in the Republic of Slovenia, one of the post-socialist EU member states. The second aim of the article is to provide an insight into the present and future status of the profession in the region by surveying the average earnings of junior translators in the Slovene and Russian translation and interpreting markets. The article is organized in 6 chapters. In Chapter 1 a brief overview of

C) Siberian Federal University. All rights reserved

* Corresponding author E-mail address: nike.pokorn@ff.uni-lj.si 
the history of Slovene language will be provided, followed by the description of the development of the profession of translators and interpreters on the Slovene market in 1980s and 1990s in Chapter 2. In Chapter 3 the article will then focus on the history of training translators and interpreters in Slovenia. Two analyses of the Slovene translation market will be presented in Chapter 4: one from 2007 and the other from 2014. In Chapter 5 two graduate surveys will be described: the first one carried out by the Department of Translation Studies of the University of Ljubljana, and the second one by CIUTI, the oldest international association of university institutes training translators and interpreters. A special attention will be paid to employment statistics and average earnings of junior translators in the Slovene and Russian translation markets. Finally, in Chapter 6 some conclusions will be drawn, and an insight into the future status of the profession in the region will be provided.

\section{The Slovene Language}

Before looking more closely at the development of the profession of translators and interpreters in a post-socialist society, let me present some basic facts about the state we are going to focus on. The Republic of Slovenia was a part of the Socialist Federal Republic of Yugoslavia from 1945 until 1991 when it became an independent state. In 2004, Slovenia joined the EU and NATO, and the Eurozone in 2007. The official language of a bit more than 2 million inhabitants is called the Slovene language.

The Slovene language is not a new, post-socialist invention: it is a South Slavic language written in the Roman alphabet and its earliest written record is found in the Freising Manuscripts, a collection of confessions and sermons dating from around 1000 AD. However, since the Slovene population was subjected to a more or less intense Germanization from the $9^{\text {th }}$ century onwards, very few examples of Slovene writings are recorded until the Reformation, when Protestants translated the Bible (1584), wrote tracts in Slovene, and published the first Slovene grammar and dictionary (see e.g. Ahačič 2007). After a fierce Counter-Reformation, the next revival of Slovene happened at the end of the 18th century when a Roman Catholic translation of the Bible and the first Slovene theatrical texts in Slovene appeared. The $19^{\text {th }}$ century brought Napoleon's army to this territory, which introduced the use of Slovene as an official language at lower levels of administration and in state schools. This change in status consequently led to the standardization and codification of the language. After the return of Habsburg rule, the national revival was not stopped: in 1849 the Slovene language effectively became one the official languages of the Austrian-Hungarian Empire (Grdina and Stabej 2002). In the interwar period when the territory inhabited by Slovenes became a part of the newly formed State of Slovenes, Croats and Serbs (1918, later renamed into the Kingdom of Serbs, Croats and Slovenes (1918-1929) and the Kingdom of Yugoslavia (1929-1945)), Slovenes continued using the Slovene language officially. After WWII Slovene became one of the three official languages of the Socialist Federal Republic of Yugoslavia, and is now the official language of the Republic of Slovenia and one of the 24 official languages of the EU (cf. Pokorn 2012).

The Slovene language and translation into Slovene have always represented one of the most important nation-building elements. It is not surprising then that the history of the development of the Slovene language and Slovene literature is closely connected to translation: from the early beginnings translations not only stand at the origins of standard Slovene, but also at the beginning of Slovene prose, poetry, and drama. The first written text in Slovene is a $10^{\text {th }}$-century 
translation of a confession formula, the most important prose work is a $16^{\text {th }}$-century translation of the Bible, and the first secular play is an $18^{\text {th }}$ century translation of a German Baroque play.

Today the Republic of Slovenia marks the southern border of Schengen area. Speaking about the future of language professions in Slovenia is thus speaking from the margins - the margins that find the activity of translation (itself also marginalized in numerous core linguistic communities (cf. Venuti 1995)) one of the most central activities safeguarding the only feature that distinguishes us from our neighbors: the Slovene language. It seems, however, that the central role the translation has always played in the process of nation building and the changes the profession of translators and interpreters have undergone during the last decades are far from being idiosyncratic and unique to Slovenia: the peripheral linguistic communities (i.e. communities using a language that only a few speakers use as their second language (see Linn 2006 for a distinction between "core" and "peripheral")) share numerous common points regarding the training of translators and interpreters and the status of the profession in the society. In order to look in the future, allow me first to look back and trace the development of translation profession in Slovenia in the last few decades.

\section{Translation and Interpreting as Profession in Slovenia from the 1980s to 2007}

When Slovenia was still part of the Socialist Federative Republic of Yugoslavia, translators, who were all graduates of traditional philological departments, found relatively well-paid jobs in large companies with strong export activities, and also enjoyed relatively high status within the company hierarchy. They were either members of the Association of Scientific and Technical
Translators of Slovenia (which was founded in 1960) or the Association of Slovene literary Translators (founded in 1953) or, indeed, the Slovene Association of Conference Interpreters, which was founded in 1973.

In the late 1980s the first free-lance translators emerged responding to the growing need for high-quality translation away from Slovene in the market (in particular into English and German). At first, they were able to make considerable profit, they could choose their clients and texts, negotiate their own fees, and some of them were even able to expand their businesses in a few years, employing two or three younger colleagues who did all the translation assignments while they only busied themselves with organizational matters. The few Slovene interpreters that worked in that period were all trained abroad and worked also with Serbo-Croat, which was more often in demand in conference settings. From 1987 onwards the departments of English and German at the University of Ljubljana provided a possibility of specialization in translation to the students in the third and fourth year of their study, but no Slovene highereducation (HE) institution provided a program completely devoted to translator or interpreter training at that time.

At the beginning of the 1990s, Slovenia became an independent republic, in 1992 it held its first multiparty election, and in June 1996 signed an agreement of associate membership with the European Union. With the possible EU membership the translator workload doubled, the entire Acquis Communautaire, that is more than 170,000 pages of accumulated legislation, legal acts, and court decisions which constitute the body of European Union law, had to be translated. The intense negotiations with the EU also increased the need for high-quality interpreters. Thus this decade saw not only the establishment of the first translation companies, but also of 
the first university program for translator and interpreter training. In 1997, the Department of Translation Studies at the University of Ljubljana University was founded, four years later in 2001 a translation program was opened at the University of Maribor, and since 2015 it is also possible to study translation at the University of Primorska, which means that nowadays one can study translation at three out of five public HE institutions in Slovenia. The program entirely devoted to interpreting, however, is run only by the Department of Translation Studies at the University of Ljubljana, whose programs also are the only ones in Slovenia that are internationally accredited.

At the beginning of the $21^{\text {st }}$ century the situation in the translation market changed considerably: the number of translation companies dramatically increased after 2003 when the changes in legislation made the establishment of small business easier and when the need for the translation of EU-related documents exceeded the capacities of governmental translation services that started to outsource the work to freelance translators and translation companies.

\section{Training of Translators}

\section{and Interpreters in Slovenia according to the Bologna Guidelines}

In order to keep up with the change, the Department of Translation Studies at the University of Ljubljana started to observe more closely the development of the local translation market. In 2003 a survey of translation practice conducted by Nataša Hirci, interviewing Slovene free-lance translators active on the translator forum within the framework of the Association of Scientific and Technical Translators of Slovenia showed that $89 \%$ of respondents besides translating into Slovene (L1) also translated into their second language, in fact, more than half of them $(62 \%)$ translated into their foreign language (English in most cases) more often than into their mother tongue. The survey also showed that the source texts in the Slovene translation market were most often written in English (81\%), and that the most common text types were technical texts, closely followed by contracts, business correspondence, legal texts, promotional texts, and EU texts. In 2003, already more than half of the respondents (55\%) indicated that they used computer-assisted translation tools in their work (Hirci 2005). In 2005, when the Department of Translation Studies at the University of Ljubljana then changed the program according to the Bologna guidelines, we included into the new programs the findings of this analysis: English was introduced as the obligatory B language, courses in translation away from Slovene were made obligatory, and elective translation seminars offered practice in the text types that were identified as the most commonly translated text types on the local translation market.

We split our 4-year program into two cycles: a 3-year BA cycle called Interlingual Communication, and a 2-year MA cycle called Translation and another 2-year program called Interpreting. The decision to call the BA program Interlingual Communication was a joint decision of the translation-training institutes in our region: similar decisions were also taken by the universities of Trieste, Graz and Vienna. In that way we tried to avoid the confusion on the labor market: according to us, graduates of a three-year BA program do not acquire all the competences needed to work as translators in the market.

In this three-year program, each student has to take three languages: Slovene as language A, English as language B and another language B, which may be French, German or Italian. The program focuses on the acquisition of following competences: 
a) language competence

The emphasis is on pragmatics, text formation and genre studies in both foreign languages and in language A (i.e. Slovene).

b) cultural competence

The program includes courses on history, literature, culture and society of all three languages, including the Slovene culture.

c) an introduction to translation competence

Students are introduced to CAT tools, the use of dictionaries, and they also start summarizing and translating texts from and into their L1.

The majority of the BA graduates (between 80 and $90 \%$ ) continue their study at the Ljubljana MA program Translation. MA program Translation focuses on the acquisition of the translation competence, which means that the great majority of the program consists of elective translation seminars. The program also includes a 3 to 6 week mandatory internship at different translation agencies and other stakeholders providing translation services in the local and other European markets. The MA program in Interpreting is an EU-funded program that typically enrolls only 5 to 7 students a year and is in its second year completely devoted to interpreting practice. The majority of the graduates find work at the EU institutions after graduation.

\section{Slovene Translation Market after 2007}

The Republic of Slovenia joined the EU and NATO in 2004, and the Eurozone in 2007 as the first of the new EU member states. For a while we were regarded as one of the best-performing new EU members, which was reflected also in the translation market. Atfirst the situation looked very promising for all the agents involved: the number of translation companies kept growing together with the need for translation in the market - in 2006, for example, Slovenia's translation industry with its $3 \%$ annual growth closely followed the
European average which stands at $4 \%$ as Boucau reports (2006). But soon, the nature of the work demanded changed. The clients wanted their translations in more than one language and also almost immediately which meant that larger and more complex translation jobs could only be tackled by teams of translators. Translation memories, terminological management and project management software became a technical characteristic of the sector, and consequently the translation fees were lowered. This means that very few self-employed freelancers working alone were able to survive. According to Boucau (2006), this development as well seemed to be in line with European trends.

New, global players entered the field: according to the survey of the market made by Darja Fišer in 2007 (Fišer 2008), there were 481 businesses registered for translation and interpreting in Slovenia, among them 75 companies and 363 sole proprietors. 10 companies that represented $2 \%$ of total number of translation businesses in Slovenia catered to more than $50 \%$ of Slovene translation market, and among those top-10 companies two of them have also been ranked among top-20 translation companies in the world. These companies used mainly external, and not in-house translators for their jobs; they acted more as intermediaries in the translation cycle, employing mainly project managers and administrative staff who took care of the financial and organizational aspect of projects, while the majority of translation work was contracted out to freelancers. Since they hired translators according to their immediate needs, those freelancers who were able to work in teams, and were more versed in the use of CAT tools had a greater chance to get a job. This means that the result was that very few self-employed freelancers working alone were able to survive.

I have looked again at the market situation in Slovenia in 2014. The main source of the 
survey was the Slovenian Business Register, a public database containing information on all business entities in Slovenia that is maintained by the Agency of the Republic of Slovenia for Public Legal Records and Related Services'. All business entities with Translation (K74.851) as their main activity were extracted from the register. This survey has shown that the translation market in Slovenia is still thriving, and that the trend outlined in 2007 still persists: the translation market is growing, however, only few companies thrive on this progress. In the period of 7 years the number of businesses registered for translation and/or interpreting has almost tripled: in 2014 there were 1.166 companies registered for translation and interpretation in Slovenia, among them

a) 1 limited partnership company, 1 cooperative, 7 institutions, (0.8\%)

b) $65(5.6 \%)$ self-employed in culture,

c) $935(80,1 \%)$ sole proprietors,

d) $157(13.5 \%)$ limited liability companies.

The majority (115 or $73 \%$ ) of these 157 limited liability companies are micro companies employing no or one person. Only 11 companies have more than 5 employees, and out of these 11 companies only 2 have more than 10 employees. However, the market share of these 11 top companies, which represent less than $1 \%$ of total number of translation businesses in Slovenia, was $29.45 \%$ in 2014. Moreover, three out of 10-top companies are associated with three international companies that were ranked by Common Sense Advisory in 2012 among top-30 translation companies in the world. ${ }^{2}$ All these developments show the continuation of the trend of globalization of the trade outlined in 2007: despite the growing number of translation business in Slovenia, a selected number of worldwide leading language service providers still maintain the largest market share in Slovenia today.
Also literary translators underwent a radical transition. During Socialist times the fee for literary translations was defined by the Ministry of Culture and was relatively high, in fact, literary translations were sometimes regarded as a means to financially support important artists, e.g. novelist, poets and dramatists. After 1991, things dramatically changed in this area as well. Government no longer financially supported selected publishing houses, many of them went bankrupt, and new, more profit-driven ones were established. The publishing houses consequently started to lower the fees, which resulted in the fact that literary translation has now become almost exclusively a part-time activity of academics, editors or professional translators. Also here, Slovene literary translators started to share the fate of their Western colleagues (cf. Bajt 2004, Terbove 2005).

Those who still persist in the profession of literary translators apply for the status of the so-called self-employed workers in culture. The status is granted to everyone who works in the field of literary translation (or theoretical translation of works for arts and sciences and media translation) and can prove to have some experience in this field (e.g. they must have created at least 480 pages of literary translation (or theoretical works in the field of arts and humanities) or 1,200 verses or 3 translations of works for stage performance or 10 movies or TV movies (or series, documentaries or cartoons)). If those who acquire this status prove that they also have limited income, the state covers their social insurance from the budget. In 2014 this meant that the applicant had had to earn less than $€ 19.928,52$ gross per year in the last three years. Since those who apply for this status mainly aim at getting the state covering their social insurance, we can assume that the majority of these 65 translators who were registered as "cultural workers" in 2014 (5.5\% of all translation businesses), fall into 
the same income category as the majority of those who work as non-literary translators, as we shall see in the following chapter.

\section{Graduate Surveys}

The analysis of the local translation market does not tell us what happens to the graduates after they finish their studies at university. In order to find answers to this question, the Department of Translation Studies of the University of Ljubljana periodically surveys its graduates.

The departmental survey in 2013 (see Fig. 1) showed that our graduates do translation-related jobs in different companies (26\%), are free-lance translators $(22 \%)$, work for translation agencies and localization companies (17\%), for the European institutions (13\%), Slovene ministries and governmental offices (13\%), are owners of translation agencies (1\%), or journalists (1\%). However, our survey is flawed: it is not obligatory, so very few graduates (in our case only 25 of them) decide to respond to it. Moreover, it seems that only those graduates who feel confident about their position are willing to answer and provide additional data on their further career.

Let us therefore look at another, much more representative survey. In March 2014 the graduates of the Department of Translation
Studies at the University of Ljubljana joined the CIUTI survey designed and carried out by Professor Peter Axel Schmitt, Lina Gerstmayer and Sarah Müller, all from the Institute for Applied Linguistics and Translatology at the University of Leipzig. The survey was sent to all members of CIUTI (Conférence Internationale Permanente des Instituts Universitaires de Traducteurs et d'Interprètes), the oldest international association of university institutes training translators and interpreters. ${ }^{3}$ The online questionnaire, carried out in March and April of 2014, was a very complex one: it consisted of 97 questions addressed to graduates of translatorand interpreter-training programs. The majority of the respondents $(60 \%)$ held an MA degree in translation and/or interpreting, a little more than $20 \%$ of them received a diploma degree before the Bologna reforms, while the rest either held a BA in translation $(12 \%)$ or a PhD degree. The majority of them were translators $(58 \%), 22 \%$ finished a degree that combined translation and interpreting, and $20 \%$ finished an interpreting studies degree only. Since the respondents fell into different groups (translators, interpreters, free-lancers, employees, etc.), the maximum number of questions an individual respondent was asked to answer was lower. However, in

\section{Graduate Employment}

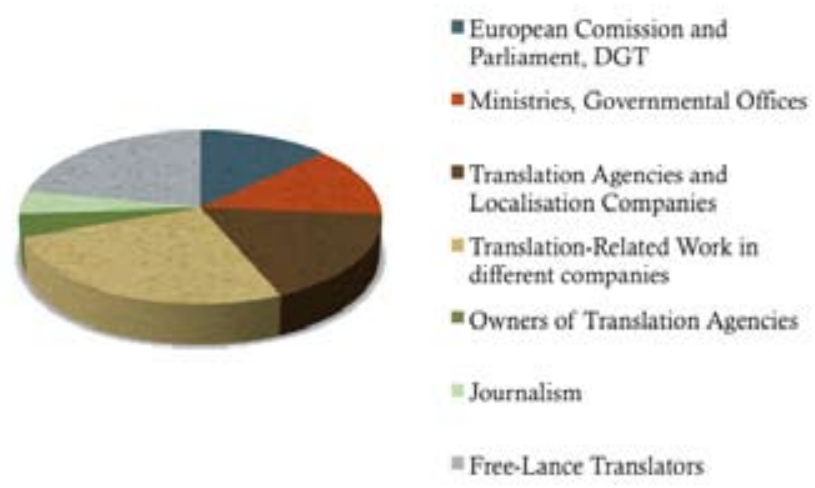

Fig. 1 Graduate Employment (Survey by the Dept. of translation, University of Ljubljana) 
some cases it reached up to 60 per person. Despite the considerable length of the questionnaire, the authors nevertheless managed to get answers from 2813 graduates from 42 translator- and interpreter-training institutes situated in 19 different countries: Austria, Australia, Belarus, Belgium, Canada, China, Czech Republic, Denmark, France, Germany, Italy, Korea, Lebanon, Russian Federation, Spain, Slovenia, Switzerland, the United Kingdom, and the United States of America. All institutes were members of CIUTI, and since some countries are represented in CIUTI by one institute only (e.g., Slovenia, Lebanon, Belarus, Czech Republic, etc.), and others by more than one (e.g., Germany, Austria, Belgium), the majority of the respondents came from Germany, Belgium, Italy, and Austria, respectively; the discrepancy between the number of respondents from different countries, however, was not so large as to influence the results (Schmitt et al. 2016).

The authors of the survey provide to the institutes that participated in the survey Excel tables with the complete survey data concerning their own institutes, and since the University of Ljubljana was one of the participants, we were able to get an insight into the responses of 141 Slovene respondents who were all graduates of either pre-Bologna 4-year study of translation (19 respondents) or of Bologna BA (84 respondents) or MA programs offered by the Department of Translation Studies at the University of Ljubljana (5 respondents graduated in interpreting, 34 in translation). I was also able to get partial results for the graduates of the four Russian institutions that were members of CIUTI in 2014. It is impossible here to present all the results of the study - let me mention just those that focus on employment statistics and average earnings.

As far as employment statistics is concerned, the results of the survey show that $16 \%$ (i.e. 23 out of 141) of Slovene respondents were unemployed in 2014 (10 graduates of MA Translation and 13 BA graduates). If we compare that with the youth unemployment rate (i.e. the share of the labor force ages 15-24 without work but available for and seeking employment) in Slovenia in 2014, which stood at $26 \%$ according to the data provided by Employment service of Slovenia ${ }^{4}$, the situation is not alarming. In addition to that, half of the unemployed MA graduates had finished their studies less than a year before the survey was taken, which indicates that it takes time to get a job in Slovenia - according to other respondents up to 10 months. However, this result is still much higher than the average unemployment rate of all CIUTI respondents, where only $8 \%$ of graduates out of 2,813 respondents indicated that they were unemployed. It is also considerably higher than the unemployment rate of the respondents from the Russian Federation: only 4 out of $104(3,8 \%)$ respondents indicated that they were unemployed, which is very low considering that the overall unemployment rate in Russia in 2014 was 5.2\%.

The CIUTI survey also provided an insight into the average earnings of the graduates. The annual income (before tax) of 28 Slovene respondents ${ }^{5}$ shows that $50 \%$ of all MA graduates earn between $€ 10,000$ and $€ 20,000$ before tax (see Fig. 2).

If we look more closely at different categories we see that all those who earn from $€ 45,000$ to $€ 80,000$ work outside Slovenia: as interpreters in Belgium or as translators in Luxembourg, Austria or Germany. Half of the respondents who earn between $€ 25,000$ and $€ 35,000$ work in Slovenia, the other half in Ireland and the UK. Those who earn less work at home, in the Republic of Slovenia, or in other Central European States (e.g. Hungary).

If we compare these results to the gross annual income in 2014 for all the graduates (BA and MA) of the Department of Translation (University of Ljubljana) that responded to this 


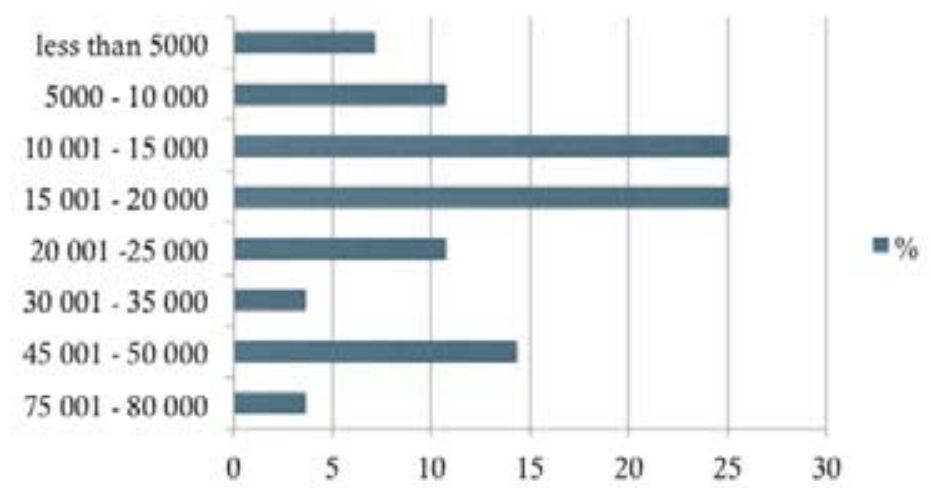

Fig. 2. 2014 Gross annual income in euros, MA graduates in translation or interpreting, Department of Translation Studies, University of Ljubljana

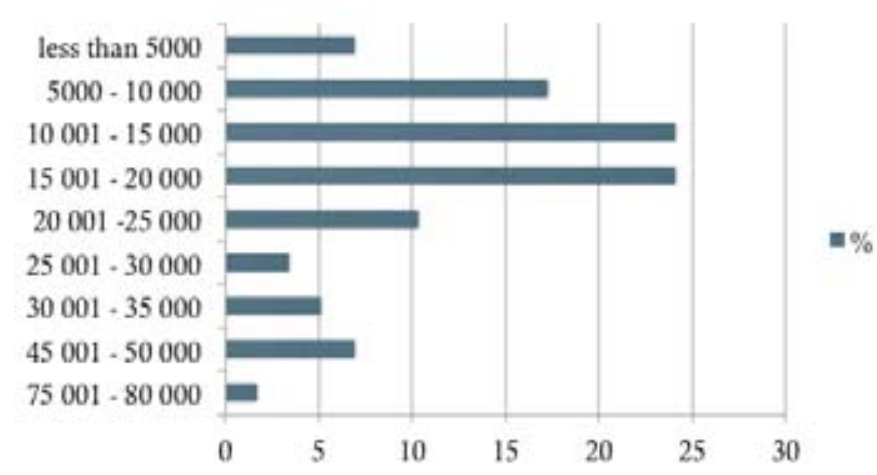

Fig. 3. 2014 Gross annual income in euros, BA and MA graduates, Department of Translation Studies, University of Ljubljana

question (58 in total), we get a very similar picture (see Fig. 3).

For comparison, the average earnings of graduates from the institutes that are members of CIUTI are higher and would range from $€ 26,000$ to $€ 30,000$ (before taxes) (Schmitt et al. 2016). Similarly also in the United States, according to the Bureau of Labor Statistics (figures are based on about 49,000 individuals who report themselves «interpreter» and/or «translator» on their tax forms), in 2014 interpreters and translators earned about $€ 39,254$ ( $\$ 43,590) .{ }^{6}$ However, the GDP $(\$ 37,246)$ and PPP $(\$ 29,866)^{7}$ in Slovenia in 2014 were also lower than those in the majority of the old EU member states or in the US.
In view of the fact that $84 \%$ of CIUTI respondents were female and born between 19771991 (i.e. from 23 to 37 year old), the majority (64\%) was born between 1984 and 1988 (i.e. from 26 to 30 year old), one can speculate that they have or at least would like to have children. However, since $24 \%$ of all respondents earned only up to $€ 10,000$ gross per year in 2014, and in 2014 the annual at-risk-of-poverty threshold for a one-member household was set at $€ 7.146$ in Slovenia,${ }^{8}$ one cannot but pessimistically conclude that a quarter of our graduates are barely coping.

The question that arises is then: How do these who earn less than $5,000 €$ per year 
survive? The responses in the survey show that $36 \%$ of our graduates have some other source of occupation, apart from their current main occupation: in fact, as many as $30 \%$ of all MA graduates combine their translation activities with a non-translator-related profession: they are either teachers of languages, work in administration or international relationships departments, or are employed as project assistants or office managers in translation agencies.

Let us look at the Russian Federation now (see Fig. 4). The results of the CIUTI survey for 84 graduates from Russian CIUTI members show that in 2014 the majority of graduates earned more than $€ 5,000$ per year (before tax), i.e. approx. 366,400 RUB, however, almost $30 \%$ of them earned less than $€ 5,000$. It is a pity that the results do not show also smaller amounts than 5000 per year. This detail would allow us to gain a more informed insight into the financial situation of the junior translators in the Russian translation market.

On the other end of the scale (see Fig. 5), however, a more detailed look at the gross annual income of the graduates from the Russian CIUTImember institutes shows that the profession of a translator or an interpreter can lead to some highpaying jobs in the field.

\section{Conclusions}

To conclude, although the status of a professional interpreter has remained relatively stable, the status of a professional translator has dramatically changed in the last few decades in Slovenia, unfortunately, not always for the better. There is no doubt that the translation market is thriving in Slovenia and the profits are getting higher, however, the status of those translators who do not work within institutions is deteriorating. The number of in-house translators has lowered and the majority of junior translators start their career as free-lance translators working for big (often international) translation companies that keep lowering their rates. It is not surprising then that the comment of one of the CIUTI respondents from Slovenia is less than encouraging: "I would like to say that it is very hard to find a job as a translator in Slovenia and it is also badly paid and underestimated."

The situation in Russia, however, does not seem to be so gloomy: this brief overview of the market shows that the graduates of four internationally recognized Russian $\mathrm{HE}$ translator- and interpreter-training institutes still get jobs and can also be very well rewarded for their work. It is safe to assume, however, that also the Russian market will become interesting for the major players in the global translation

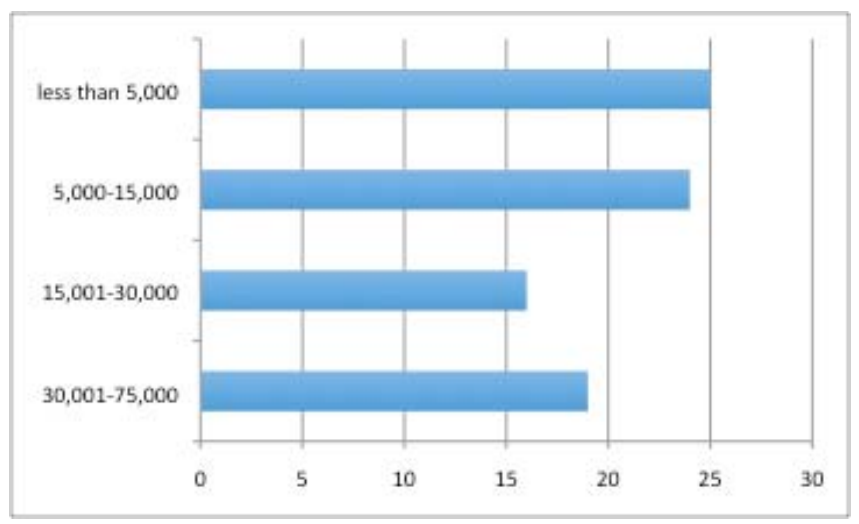

Fig. 4. 2014 Gross annual income in euros, graduates of CIUTI members from Russian Federation 


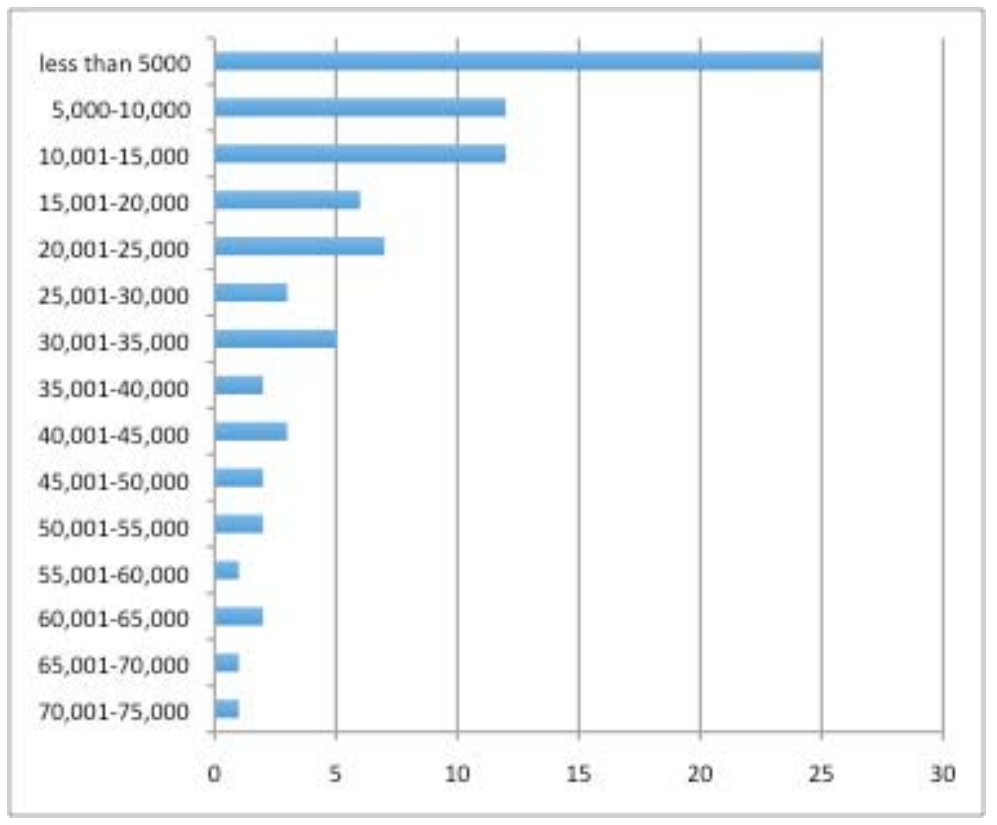

Fig. 5. 2014 A more detailed gross annual income in euros, graduates of CIUTI members from Russian Federation

market and that the changes similar to those in Slovenia (and the rest of Western Europe) will transform the Russian translation market as well.

The future of the profession of translators and interpreters is thus bound to be linked to the development of translation and interpreting market which is constantly changing: it is subject to globalization of the trade, the biggest players in the field rely more and more on outsourcing, and a skillful use of technologies has become an essential part of translators' work. In such a world the role of professional associations is central: they will have to focus their efforts on the need to upgrade working conditions and remuneration of translators in local markets. The translators and interpreters themselves, however, will also have to be prepared to be as flexible as possible, to combine and expand their competences, and to accommodate quickly to rapid changes dictated by the market needs.

\footnotetext{
http://www.ajpes.si [26 September 2014]

www.commonsenseadvisory.com (accessed 18 October 2015)

http://www.ciuti.org/ (accessed 18 October 2015)

4 See https://www.rtvslo.si/gospodarstvo/brezposelnih-mladih-ze-vec-kot-cetrtina/331682 and http://www.ess.gov.si/trg _ dela/trg_dela_v_stevilkah/registrirana_brezposelnost (accessed 18 October 2015)

Not all of the respondents answered this question.

6 http://www.bls.gov/oes/current/oes273091.htm (accessed 19 October 2015)

7 World Economic Outlook Database, http://www.imf.org/external/pubs/ft/weo/2015/02/weodata/index.aspx (accessed 19 October 2015)

8 Statistical Office of the Republic of Slovenia, http://www.stat.si/StatWeb/prikazi-novico?id=5426\&idp=10\&headerbar=8 (accessed 19 October 2015)
} 


\section{References}

Ahačič, K. (2007). Zgodovina misli o jeziku in književnosti na Slovenskem: protestantizem. Ljubljana, Založba ZRC, ZRC SAZU, 416 p.

Bajt, A. (2004). Družbena podoba prevajalca leposlovja v Sloveniji. BA thesis. Ljubljana: [Andreja Bajt] Department of Translation Studies, University of Ljubljana, 60 p.

Boucau, F. (2005). The European Translation Industry: Facing the Future. Brussels 2005. Available at: www.guilde.net/fr/news/euatc.pps (accessed 20 September, 2013).

Fišer, D. (2008). Recent trends in the translation industry in Slovenia. In The journal of specialised translation, issue 10. Available at: http://www.jotrans.org/issue10/art_fiser.pdf (accessed 18 February, 2016).

Grdina, I. \& Stabej, M. (2002). Slowenisch. In Enzyklopädie des Europäischen Ostens. Available at: http://wwwg.uni-klu.ac.at/eeo/Slowenisch.pdf (accesed 14 February, 2016).

Hirci, N. (2005). Prevajanje v nematerni jezik: tabu ali nuja? In Beyond Equivalence, Jenseits der Äquivalenz, Oltre l'equivalenza, Onkraj ekvivalence (Nike K. Pokorn, Erich Prunč and Alessandra Riccardi (eds)). Graz, Institut für Teoretische und Angewandte Translationswissenschaft, Universität Graz, 87-104.

Linn, S. (2006). Trends in translation of a minority language: The case of Dutch. In Sociocultural Aspects of Translating and Interpreting (Anthony Pym, Miriam Shlesinger \& Zuzana Jettmarová (eds.)). Amsterdam, Philadelphia, John Benjamins, 27-40.

Pokorn, N. K. (2012). Post-socialist translation practices: ideological struggle in children's literature. Amsterdam, Philadelphia, John Benjamins, 188 p.

Schmitt, P. A., Gerstmeyer, L. \& Müller, S. (2016). Übersetzer und Dolmetscher - Eine internationale Umfrage zur Berufspraxis. Berlin, DBÜ Fachverlag.

Terbovc, Š. (2005). Položaj književnega prevoda na Slovenskem med letoma 1997 in 2004. BA thesis. Ljubljana: [Š. Terbovc] Department of Translation Studies, University of Ljubljana, 102 p.

Venuti, L. (1995). The Translator's Invisibility. London, New York, Routledge, 345 p. 


\title{
Диктат рынка. \\ Будущее профессии письменного и устного переводчика \\ в постсоциалистическом государстве - члене ЕС
}

\author{
Нике К. Покорн \\ Люблянский университет \\ 2 Ашкериева, 1000 Любляна, Словения
}

В статье рассматриваются изменения в профессии письменных и устных переводчиков, а также развитие обучения письменных и устных переводчиков на университетском уровне за последние 35 лет в Республике Словения, одной из постсоциалистических стран ЕС. Статья дает представление о настоящем и будущем статусах профессии путем опроса о размере среднего заработка молодых переводчиков на словенском и российском переводческих рынках. На основе анализа общедоступной базы данных, содержащей информацию о всех субъектах деятельности в Словении, выполнено описание переводческого рынка в 2014 году. Полученнье результаты были сопоставлены с результатами аналогичного исследования, проведенного в 2007 году, при этом особое внимание уделено изменениям, произошедиим в результате аутсорсинга и глобализаџии профессии. В заключении представлен опрос выпускников кафедры переводоведения Люблянского университета, а также четырех переводчиков из России, являющихся членами Международной ассоцииции университетов, реализующих программы подготовки переводчиков (CIUTI), фокусируемый, прежде всего, на статистике занятости выпускников и средних заработках молодых письменных и устных переводчиков. На основе описания современного состояния профессии был сделан вывод о том, что на будущее профессии письменных и устных переводчиков будут влиять глобализация переводческого бизнеса, сокращчение числа переводчиков, являющихся постоянными сотрудниками в конкретных организациях, а также возрастание использования технологии, которая сделает письменных и устных переводчиков гибкими, готовыми к приобретению новых навыков и быстрому адаптированию к потребностям рынка.

Ключевые слова: переводческий рынок, профессиональные письменные и устные переводчики, глобализачия переводческого бизнеса, обучение письменных и устных переводчиков, размер среднего заработка письменных и устных переводчиков в Словении и России.

Научная специальность: 10.00.00-филологические науки. 